\title{
Comparative Evaluation of the Effects of Organic and Inorganic Fertilizers on the Vegetative Growth of Spleen Amaranth (Amaranthus dubius L)
}

\author{
*1AHMAD, AT; ${ }^{2}$ BELLO, IU, ${ }^{3}$ JIBRIL, SM; ${ }^{1}$ KOLAWOLE, OS; ${ }^{1}$ OGAH, JJ; \\ ${ }^{1}$ DANIEL, $S$ \\ ${ }^{* 1}$ Department of Biological Sciences, Faculty of Science, ${ }^{2}$ Department of Animal Science, Faculty of Agriculture, Federal University of \\ Kashere, Gombe State, Nigeria. \\ ${ }^{3}$ Department of Biological Sciences, Alqalam University, Katsina, Katsina State, Nigeria. \\ *Correspondent Author Email: atahmadyakasai@gmail.com Tel: +2348031804974
}

\begin{abstract}
The application of organic and inorganic fertilizers to the soil is considered as good agricultural practice because they improve the fertility of the soil and plant quality. The overall objective of the study is to compare the effects of organic fertilizers (cow dung and chicken droppings) with inorganic fertilizer (urea) on the vegetative growth of Amaranthus dubius. The data obtained showed that, levels of all parameters measured for both the organic and inorganic fertilizers ranges; Stem length $(7.5-64.2) \mathrm{cm}$, Stem width $(2.4-8.1) \mathrm{cm}$, Leaf length $(8.0-19.3) \mathrm{cm}$, Leaf width (3.3-14.2) $\mathrm{cm}$ and Number of leaves per plant (09-34). The mean values for the stem length, stem width, leaf length, leaf width and number of leaves per plant were evaluated and found to be higher in plants grown with urea treatment compared to values obtained from the treatments with organic manures. Data were analyzed using One-way Analysis of Variance (ANOVA) and the results were expressed as percentage difference, the differences between the mean values were determined at $95 \%$ confidence. Inorganic fertilizer resulted in significant effects at $(\mathrm{p}<0.05)$ compared to values obtained from the organic manures.
\end{abstract}

\section{DOI: $\underline{\text { https://dx.doi.org/10.4314/jasem.v23i2.24 }}$}

Copyright: Copyright (C) 2019 Ahmad et al. This is an open access article distributed under the Creative Commons Attribution License (CCL), which permits unrestricted use, distribution, and reproduction in any medium, provided the original work is properly cited.

Dates: Received: 16 December 2018; Revised: 20 January 2019; Accepted 16 February 2019

Keywords: Amaranthus dubius, Chicken droppings, Cow dung, Urea.

Amaranthus dubius is an annual herb native to South America, Mexico and West Indies. This species has been widely introduced as a green vegetable for human consumption and as a medicinal herb. It has escaped from cultivation and now is considered casual or naturalized mainly in tropical and subtropical regions of Africa, Asia, Australia and the Pacific (Dunlop et al., 2005). The family Amaranthaceae has more than 80 species of which about 60 are considered weedy and about 50 are consumed as pot- herbs or leafy vegetables worldwide (Janick, 2006; Olufolaji, 2007). Schippers (2000) noted that all species found in Africa are grown for their leaves. Some varieties were introduced from America for grain production but this is not very popular in Africa. There is no distinct separation between vegetable and grain type species since even the leaves of young grain type plant can be eaten as leafy vegetables. The most popular leafy species are A. dubius, A. hybridus, A. hypochondriacus, A. tricolor, A. blitum and the most frequently cultivated species in Asia is A. tricolor, but is hardly ever seen in Africa (Schippers, 2000). Amaranthus dubius is morphologically similar to $A$. hybridus and A. powellii. It differs from these species by having bracks shorter than tepals (long less than $2 \mathrm{~mm}$ ) and stronger spreading style branches (Dunlop et al., 2005). A. dubius has a short life-cycle, each produces a high number of seeds. The emergence of the seedling takes 2-4 days after sowing. Flowering starts after 5-7 weeks and it produces new shoots when older branches are already blooming (Grubben, 2004). Sigh et al. (2001) noted that A. dubius is an important source of vitamins especially vitamin A, the lack of which results in a most serious nutritional deficiency in the tropics and leads to blindness in thousands of children each year. The leaves are also a good source of vitamin $\mathrm{C}, \mathrm{K}$ and folate, and when compared to spinach, A. dubius contains 3 times more vitamin $\mathrm{C}$, calcium, iron and niacin. It contains 18 times more vitamin A, 20 times more calcium and 7 times more iron when compared to lettuce, the leaves have high levels of carotene and micro nutrients such as sodium, copper, manganese chloride (Mnkeni et al., 2007). The main habitats in which A. dubius occurs are tropical forest, humid lowland waste areas, vegetable gardens and roadsides (Mosyakim and Robertson, 2003). Pollination is by wind or insects, and they are monoecious or dioecious (FAO, 2008). Amaranthus 
dubius spreads by seeds, it is a prolific seed producer. Seeds are dispersed by wind, water, birds and as a contaminant in pasture and crop seeds and attached to agricultural machinery. The seeds of A. dubius are smaller than that of other cultivated amaranths, with 4000-6000 seeds/g. It germinates when it comes to the surface or in the top $3 \mathrm{~cm}$ of the soil and germination is stimulated by darkness (Grubben, 2004). The seeds may be mixed with sand for easier sowing. It is common practice to sow directly, broadcast or in rows with about $1 \mathrm{~cm}-20 \mathrm{~cm}$ between rows, with seed rate of $1-5 \mathrm{~g} / \mathrm{m}^{2}$. Another cultivation method is sowing in a nursery at a rate of $2-10 \mathrm{~g} / \mathrm{m}^{2}$ and transplanting after 12 weeks (Chen and $\mathrm{Wu}, 2007$ ). If rainfall is not sufficient, irrigation by sprinkling should be done before the plants reach their wilting point. A. dubius is much more susceptible to drought than A. cruentus. Watering everyday with $6 \mathrm{~mm}$ is sufficient. Water shortage causes early flowering, which reduces the yield and the market quality (Onyanga, 2010). The main aim of this research is to compare the effects of organic and inorganic fertilizers on the vegetative growth of Amaranthus dubius.

\section{MATERIALS AND METHOD}

Collection of Seeds and Fertilizers: The Amaranthus dubius seeds (improved variety) and urea were bought from Vegetable Market popularly known as Kasuwan Gwari, Jimeta-Yola, Adamawa State. Cow dung was sourced from cattle rearers of Kashere town while chicken droppings from the Poultry Farm of Federal University of Kashere, Gombe State.

Preparation of the Beds: Following the clearance of the field, the soil was tilled using African hoe. A measuring tape and a hoe were used to measure a gross plot of 12 by 12 metres square. The gross plot was further divided into twelve equal net plots and each net plot was measured 3 by 2 metres square. The distance between the net plots and the treatments is $0.5 \mathrm{~m}$ (Nurse, et al., 2006). The four treatments were identified randomly as M1, M2, M3 and M4 for zero fertilizer, cow dung, chicken droppings and urea respectively.

Sowing of the Seeds: The seeds at the rate of $0.075 \mathrm{~kg}$ mixed with $5 \mathrm{ml}$ of triazine (insecticide) and later on mixed with sand were planted by broadcasting. After germination, the seedlings were transplanted at a space of $0-18 \mathrm{~cm}$ and a distance of $0.5 \mathrm{~m}$ between the net plots and the treatments (Chen et al., 2007).

Application of Fertilizers: All fertilizers used for the study (cow dung, chicken droppings and urea) were quantified at $0.3 \mathrm{~kg}(300 \mathrm{~g})$ using triple beam balance and a container for each net plot. Both cow dung and chicken droppings were thoroughly spread and mixed with the soil before broadcasting the seeds because they gradually incorporate into the soil compared to urea which takes only 2-4 days, while urea was applied a week after germination. Urea contains nitrogen only; if applied before planting or less than 6 days after seeds germination, it may burn the seedlings or suppress their growth thereby leading to the death of the plants (Sanchez, 2011).

Watering and Weeding: After sowing the seeds, the beds were watered twice, morning and evening (in the absence of rainfall). The volume of water used for each net plot/bed at any watering time was 18-20 litres because $A$. dubius plants neither require too much moisture nor dryness. According to Onyanga (2010) A. dubius should be watered with sufficient water: water shortage causes early flowering which reduces the yield and the market quality. Onyanga (2010) also reported that too much of water washes the seeds away from the plots due to their lightness and high dryness also makes the plants to sprout and wilt, thereby causing them to become yellow in colour and finally die off. Normally, Amaranthus dubius seeds have variability in germination. For this reason, some seeds started germinating on the second day after planting while others on the third and fourth days.

The weeding was done whenever the need arises using hands (selective weeding) for the weeds on the beds and African hoe for the weeds found in-between the rows/net plots, according to FAO (2008) and no known herbicide is reported due to the variability in the seeds germination.

Pests and Pathogens Control: The plants were controlled using Emamectine benzoate to control bollworms, leaf worms and other worms that affect the leaves. $10 \mathrm{ml}$ of emamectine benzoate was diluted in 25 litres of water and spread on the gross plot using knapsack sprayer. Another chemical known as Triazine was also used to control insects affecting the plants, whereby, $5 \mathrm{ml}$ was diluted in $25 \mathrm{ml}$ of water and spread using knapsack sprayer. Triazine was also mixed with the seeds before broadcasting in order to kill insects or chase them away from the field (Onyanga, 2010).

\section{RESULTS AND DISCUSSION}

There were four treatments; zero fertilizer, cow dung, chicken droppings and urea which were randomly identified as M1, M2, M3 and M4 respectively. The parameters observed and measured were the stem length, stem width, leaf length, leaf width and number of leaves per plant. The data were collected five times; at the second, third, fourth, fifth and seventh weeks after germination. 
Measurement of the Stem Length: Table 1 shows the results obtained from the measurement of the stem length. The table indicates urea treatment as having the longest stem throughout the weeks with a maximum length of $64.2 \mathrm{~cm}$ at the seventh week, followed by chicken droppings, cow dung and zero fertilizer having a maximum length of $44.5 \mathrm{~cm}$, $31.0 \mathrm{~cm}$ and $16.7 \mathrm{~cm}$ respectively.

Table 1: Measurement of the Stem Length

\begin{tabular}{lcccc}
\hline Weeks after & \multicolumn{4}{c}{ Treatments } \\
\cline { 2 - 5 } Germination & M1 & M2 & M3 & M4 \\
\hline Second & $2.2 \mathrm{~cm}$ & $7.5 \mathrm{~cm}$ & $14.2 \mathrm{~cm}$ & $24.0 \mathrm{~cm}$ \\
Third & $4.0 \mathrm{~cm}$ & $12.2 \mathrm{~cm}$ & $21.0 \mathrm{~cm}$ & $28.0 \mathrm{~cm}$ \\
Fourth & $6.4 \mathrm{~cm}$ & $14.4 \mathrm{~cm}$ & $30.3 \mathrm{~cm}$ & $35.4 \mathrm{~cm}$ \\
Fifth & $6.4 \mathrm{~cm}$ & $14.4 \mathrm{~cm}$ & $30.3 \mathrm{~cm}$ & $35.4 \mathrm{~cm}$ \\
Seventh & $16.7 \mathrm{~cm}$ & $31.0 \mathrm{~cm}$ & $44.5 \mathrm{~cm}$ & $64.2 \mathrm{~cm}$ \\
\hline KEY: M1 - Zero fertilizer; & M2 - Cow dung; & M 3 - Chicken \\
droppings; M4 - Urea & & &
\end{tabular}

Measurement of the Stem Width: The results obtained from the measurement of the stem width are shown in Table 2. Plants treated with urea are found to have the thickest stem throughout the weeks with a maximum width of $8.1 \mathrm{~cm}$ at the seventh week, followed by those treated with chicken droppings $(5.1 \mathrm{~cm})$, cow dung $(4.4 \mathrm{~cm})$ and zero fertilizer $(3.0 \mathrm{~cm})$.

Table 2: Measurement of the Stem Width

\begin{tabular}{lcccc}
\hline Weeks after & \multicolumn{4}{c}{ Treatments } \\
\cline { 2 - 5 } Germination & M1 & M2 & M3 & M4 \\
\hline Second & $0.5 \mathrm{~cm}$ & $2.4 \mathrm{~cm}$ & $3.0 \mathrm{~cm}$ & $4.5 \mathrm{~cm}$ \\
Third & $1.2 \mathrm{~cm}$ & $2.1 \mathrm{~cm}$ & $3.1 \mathrm{~cm}$ & $5.2 \mathrm{~m}$ \\
Fourth & $2.1 \mathrm{~cm}$ & $3.6 \mathrm{~cm}$ & $5.0 \mathrm{~cm}$ & $7.0 \mathrm{~cm}$ \\
Fifth & $2.5 \mathrm{~cm}$ & $3.2 \mathrm{~cm}$ & $5.0 \mathrm{~cm}$ & $6.4 \mathrm{~cm}$ \\
Seventh & $3.0 \mathrm{~cm}$ & $4.4 \mathrm{~cm}$ & $5.1 \mathrm{~cm}$ & $8.1 \mathrm{~cm}$
\end{tabular}

KEY: M1 - Zero fertilizer; M2 - Cow dung; M3 - Chicken droppings; $M 4$ - Urea

Measurement of the Leaf Length: Table 3 shows the results obtained from the measurement of the leaf length. Urea treatment has the highest length throughout the period of the study with a maximum value of $19.3 \mathrm{~cm}$, followed by chicken droppings, cow dung, and zero fertilizer with a maximum height of $17.0 \mathrm{~cm}, 16.1 \mathrm{~cm}$ and $9.2 \mathrm{~cm}$ respectively.

Table 3: Measurement of the Leaf Length

\begin{tabular}{lllll}
\hline Weeks after & \multicolumn{4}{c}{ Treatments } \\
\cline { 2 - 5 } Germination & M1 & M2 & M3 & M4 \\
\hline Second & $2.3 \mathrm{~cm}$ & $8.0 \mathrm{~cm}$ & $10.0 \mathrm{~cm}$ & $14.2 \mathrm{~cm}$ \\
Third & $3.2 \mathrm{~cm}$ & $10.0 \mathrm{~cm}$ & $10.7 \mathrm{~cm}$ & $16.0 \mathrm{~cm}$ \\
Fourth & $6.3 \mathrm{~cm}$ & $7.1 \mathrm{~cm}$ & $9.3 \mathrm{~cm}$ & $12.0 \mathrm{~cm}$ \\
Fifth & $9.0 \mathrm{~cm}$ & $9.1 \mathrm{~cm}$ & $13.0 \mathrm{~cm}$ & $16.0 \mathrm{~cm}$ \\
Seventh & $9.2 \mathrm{~cm}$ & $16.1 \mathrm{~cm}$ & $17.0 \mathrm{~cm}$ & $19.3 \mathrm{~cm}$ \\
\hline KEY: M1 - Zero fertilizer; & M2 - Cow dung; & M3 - Chicken \\
droppings; M4 - Urea & &
\end{tabular}

Measurement of Leaf Width: Table 4 shows urea treatment as the treatment which has the highest leaf width throughout the period with a maximum value of $14.2 \mathrm{~cm}$, followed by chicken droppings, cow dung and zero fertilizer with $9.1 \mathrm{~cm}, 8.0 \mathrm{~cm}$ and $5.5 \mathrm{~cm}$ as at the seventh week respectively.

Table 4: Measurement of the Leaf Width

\begin{tabular}{lcccc} 
Weeks after & \multicolumn{4}{c}{ Treatments } \\
\cline { 2 - 5 } Germination & M1 & M2 & M3 & M4 \\
\hline Second & $2.1 \mathrm{~cm}$ & $3.3 \mathrm{~cm}$ & $5.0 \mathrm{~cm}$ & $8.0 \mathrm{~cm}$ \\
Third & $2.2 \mathrm{~cm}$ & $4.0 \mathrm{~cm}$ & $7.1 \mathrm{~cm}$ & $10.0 \mathrm{~cm}$ \\
Fourth & $3.0 \mathrm{~cm}$ & $5.1 \mathrm{~cm}$ & $8.0 \mathrm{~cm}$ & $11.2 \mathrm{~cm}$ \\
Fifth & $5.0 \mathrm{~cm}$ & $5.0 \mathrm{~cm}$ & $7.0 \mathrm{~cm}$ & $12.4 \mathrm{~cm}$ \\
Seventh & $5.5 \mathrm{~cm}$ & $8.0 \mathrm{~cm}$ & $9.1 \mathrm{~cm}$ & $14.2 \mathrm{~cm}$ \\
\hline KEY: M1 - Zero fertilizer; & M2 & - Cow dung; & M3 - Chicken \\
droppings; M4 - Urea & &
\end{tabular}

Number of Leaves per Plant: The results obtained for the number of leaves per plant are shown in Table 5. Based on the data, urea treatment provides the highest number of leaves with 34 leaves, followed by Chicken droppings, cow dung and zero fertilizer which provides 28, 24 and 13 leaves as at the seventh week of the study respectively.

Table 5: Number of Leaves per Plant

\begin{tabular}{lllll}
\hline Weeks after & \multicolumn{4}{c}{ Treatments } \\
\cline { 2 - 5 } Germination & M1 & M2 & M3 & M4 \\
\hline Second & 4 & 9 & 13 & 19 \\
Third & 8 & 10 & 13 & 20 \\
Fourth & 10 & 12 & 14 & 34 \\
Fifth & 13 & 14 & 16 & 23 \\
Seventh & 13 & 24 & 28 & 34 \\
\hline KEY: M1 - Zero fertilizer; & M2 - Cow dung; &
\end{tabular}

The data gathered were subjected to Statistical Analysis and were analyzed using One-way Analysis of Variance (ANOVA) and the results were expressed as percentage differences, the differences between the mean values were determined at $95 \%$ confidence. Urea treatment was found to have a significant difference at $(\mathrm{p}<0.05)$ on the vegetative growth of Amaranthus dubius when compared with the other organic manures. From this research, urea treatment is found to produce plant with the highest height of $64.2 \mathrm{~cm}$, followed by chicken droppings, cow dung and zero fertilizer with $44.5 \mathrm{~cm}, 31.0 \mathrm{~cm}$ and $16.7 \mathrm{~cm}$ respectively. Similar results were obtained by Olaniyi, et al., (2008) who reported increased Amaranthus plant height at higher nitrogen application rate. The research is also in agreement with the report of Olufolaji (2007) who reported that Amaranthus plants require high nitrogen content for their vegetative growth. Also, the increase in number of leaves with urea confirmed the role of nitrogen in promoting vigorous vegetative growth in leafy vegetables as reported by Myers, (1998) and Olaniyi, (2007). The higher stem length observed with urea treatment is also supported by Alonge, et al., (2007) who reported that nitrogen caused increase in plant height. The 
finding also agrees with Pospisil, et al., (2006) who reported that higher levels of nitrogen application produced significantly taller and broader Amaranthus plants. Moreover, the results of the research indicate that urea provides higher effects on all the parameters investigated when compared to the cow dung, chicken droppings and zero fertilizer and this can be compared with results obtained from similar researches conducted on different plants that reported increases with urea on their vegetative growth and mineral contents (Abdulrazzaq, 2002; Babatola and Olaniyi 2013; Coolong, et al., 2005; Adekayode, 2004; Fatima et al., 2007).

Conclusion: In all the parameters observed, treatment with urea shows the highest effects followed by the chicken droppings and then cow dung when compared to the zero fertilizer. But it would be highly recommended for farmers to use the organic fertilizers despite their lesser effect because this research was conducted within a short period of time which would not allow the full effects of the organic fertilizers to manifest as their incorporation to the soil takes much time than the inorganic which takes only 2-4 days. It is also less hazardous to the soil quality and health of the consumers.

\section{REFERENCES}

Abdulrazzaq, A (2002). Effects of Chicken Manure, Sheep Manure and Inorganic Fertilizer on Yield and Nutrients Uptake by Onion. Pak. Biol. Sci., 266-268.

Adekayode, FO (2004). The Use of Manure to Increase the Yield and Quality of Amaranthus to Feed Rabbit in a Humid Tropical Region. J. Anim. Vet. Adv.,3:758-762.

Alonge, SO; FO Alonge; SP Bako; JD Olarewaju; OB Adeniyi (2007). The Effects of Rates and Split Application of Compound NPK Fertilizer on the Growth and Yield of three Amaranthus Species in Nigeria Guinea Savanna. Asian J. Plant Sci., 6:906-912.

Babatola, LA; Olaniyi, JO (2013). Performance of Amaranthus caudatus at Diff. Levels of NPK Fertiliz. \& Under Diff. Storage Methods, Proceeds. 16th Ann. Conf. of Hort. Soc. of Nig., UNAAB, Abeaokuta, pp. 36-40.

Chen, S; Wu, M (2007). Note on Four Newly Nationalized Plants in Taiwan. Taiwania, 52(1): 59-69. http://taiz.ntu.edu.tw/taiwania.
Coolong, TW; DA Kopsell; DE Kopell; WM Randle (2005). Nitrogen and Sulfur Influence Nutrient Usage and Accumulation in Onion. J. Plant Nutr., 27:1667-1686.

Dunlop, E; Hardcastle, J; Shah, NJ (2005). Cousin and Cousine Islands Status and Management of Alien Invasive Species.

Elmar, K; Wolfang, W (1990). Organic Manures-No Alternative to Mineral Fertilizers for Developing Countries. BASF Agriculture News, 2:90, pp. 820.

FAO (2008). Food and Agriculture Organization. Organic Material as Fertilizers. Longman/FAO. Rome, Italy.

Fatima, AMS; Rizk, A; Singer, SM (2007). Growing Onion Plants without Chemical Fertilizer. Res. J. Agric. Biol. Sci, 3:95-104.

Grubben, GJ (2004). Amaranthus dubius Mart.ex Thell. PROTA 2: Vegetables/Legumes Wageningen, Netherlands: PROTA. 19:16-17.

Janick, J (2006). Int'l Symp. on Domest. Prod. and Utiliz. of New Crops. In: New Crop Improv.: Agro. and Hort. pp. 109-112, (Smatt and Hag, eds). Univ. of Southampton, UK.

Mnkeni, AP; Masika, P; Maphala, M (2007). Nutritional Quality of Vegetable and Seed from Different Accessions of Amaranthus in South Africa /sup. Water SA, 3(3).

Mosyakim, SL; Robertson, KR (2003). Amaranthus L. Flora of North America Editorial Committee (Magnoliophyta: Caryophyllyodae, Part 1), 4:410-435.

Myers, RL (1998). Nitrogen Fertilizer Effect on Grain Amaranth. Agron. J., 90(5). 597-602.

Nurse, RE; Obied, K; Pag, ER (2006). Optimal Planting Date. Row width \& Critic. Weed-free Period for Grain Amaranth \& Quinoa Grown in Ontario, Canada. Can. J. of Plant Science.

Olaniyi, JO; Adelasoye, KA; Jegede, CO (2008). Influence of Nitrogen Fertilizer on the Growth, Yield and Quality of Amaranthus dubius. World. J. Agric. Sciences, 4:506-513.

Olaniyi, JO (2007). Evaluation of Yield and Quality Performance of Grain Amaranth Varieties in the S/W Nig. Res. J. of Agro. 1(2):42-45. 
Olufolaji, AO (2007). Response of Four Amaranthus Cultivars to N Levels and Harvesting Methods. Tests Agrochemicals Cultivars 10:166-167.

Onyanga, CM (2010). Preharvest and Postharvest Factors Affecting Yield and Nutrient Content of Vegetable Amaranth (Var. Amaranthus hypochondriacus).

Pospisil, A; Pospisil, M; Varga, B; Svecjak, Z (2006). Grain Yield of Protein Concentration of Two Amaranth Species (Amaranthus spp.) as Influenced by the Nitrogen Fertilization. Euro. $J$. of Agro. 25:250-253.
Sanchez, PA (2011). Changing Tropical Soil Fertility Research, Towards the Second Paradigm, Trans. 15th world Congress of Soil, Acapulco, Mexico. $1: 65-88$

Schippers, RR (2000). African Indigenous Vegetables. An Overview of the Cultivated Species. Nat. Resrc. Inst./ACP-EU Tech. Cntr of Agric. \& Rural Cooprtn., Chatham, UK. pp.214.Sigh, G; Kawatra, A; Sehgal, S (2001). Nutritional Composition of Selected Green Leafy Vegetables, Herbs \& Carrots. Plant Food for Human Nutrition. 56(4), 359-364. 